\section{Pacific Northwest}

National Laboratory

Operated by Battelle for the

U.S. Department of Energy

\title{
FY04 SWIR CRDS Summary Report
}

\author{
R. M. Williams \\ J. S. Thompson \\ T. L. Stewart \\ B. J. Tweedy
}

October 2004

Prepared for the U.S. Department of Energy under Contract DE-AC05-76RL01830 


\title{
DISCLAIMER
}

This report was prepared as an account of work sponsored by an agency of the United States Government. Neither the United States Government nor any agency thereof, nor Battelle Memorial Institute, nor any of their employees, makes any warranty, express or implied, or assumes any legal liability or responsibility for the accuracy, completeness, or usefulness of any information, apparatus, product, or process disclosed, or represents that its use would not infringe privately owned rights. Reference herein to any specific commercial product, process, or service by trade name, trademark, manufacturer, or otherwise does not necessarily constitute or imply its endorsement, recommendation, or favoring by the United States Government or any agency thereof, or Battelle Memorial Institute. The views and opinions of authors expressed herein do not necessarily state or reflect those of the United States Government or any agency thereof.

\author{
PACIFIC NORTHWEST NATIONAL LABORATORY \\ operated by \\ BATTELLE \\ for the \\ UNITED STATES DEPARTMENT OF ENERGY \\ under Contract DE-AC05-76RL01830
}

Printed in the United States of America
Available to DOE and DOE contractors from the Office of Scientific and Technical Information,
P.O. Box 62, Oak Ridge, TN 37831-0062;
ph: (865) 576-8401
fax: $(865)$ 576-5728
email: reports@adonis.osti.gov

\begin{abstract}
Available to the public from the National Technical Information Service, U.S. Department of Commerce, 5285 Port Royal Rd., Springfield, VA 22161 ph: (800) 553-6847 fax: $(703) 605-6900$ email: orders@ntis.fedworld.gov online ordering: http://www.ntis.gov/ordering.htm
\end{abstract}

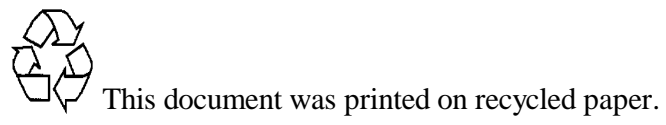




\title{
FY04 SWIR CRDS Summary Report
}

\author{
R. M. Williams \\ J. S. Thompson \\ T. L. Stewart \\ B. J. Tweedy
}

October 2004

Prepared for the U.S. Department of Energy

under Contract DE-AC05-76RL01830

Pacific Northwest National Laboratory

Richland, Washington 99352 



\section{Summary}

The principal goal of Pacific Northwest National Laboratory's (PNNL's) Infrared Technology for Advanced Sensors Project is to explore and develop the science and technology behind point and stand off infrared (IR) spectroscopic chemical sensors that are needed for detecting weapons proliferation activity. The primary use of the technology is to detect the chemical signatures associated with the production or use of chemical, biological, or nuclear weapons.

In FY04 PNNL continued the development of a Shortwave Infrared (SWIR) point sensor based on optical Cavity Ringdown Spectroscopy (CRDS). During the year this instrument participated in 3 field tests, including the indoor $\mathrm{UF}_{6}$ release experiment which took place on the Hanford Site in Aug. 2004.

The field tests demonstrated the robustness of CRDS as a fieldable technology for sensitive detection of airborne analytes. The instrument was altered from detecting ammonia with a detection limit of $\sim 1 \mathrm{ppm}_{\mathrm{v}}$ to detect hydrogen fluoride with a detection limit of $\sim 3 \mathrm{ppb}_{\mathrm{v}}$. The differences in limits of detection between these two chemicals is accounted for by the relative differences in the absorption strength of the two molecules (with HF having a much larger absorption strength than ammonia). In addition to the field tests, the instrument underwent further refinement to improve long term stability. These enhancements resulted from improvements in both hardware and software.

We outline all of these accomplishments in detail in the body of this report. 


\section{Contents}

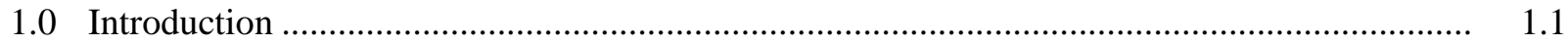

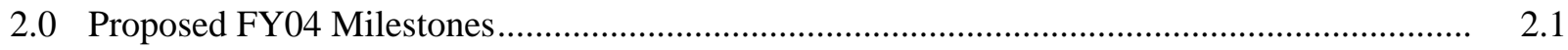

3.0 FY04 Accomplishments .................................................................................. 3.1

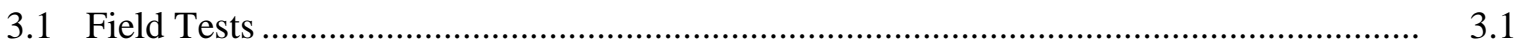

3.1.1 Second Warehouse Field Test ............................................................... 3.1

3.1.2 Outdoor HF Release Test ..................................................................... 3.3

3.1.3 U-Plant UF6 Release Test ..................................................................... 3.6

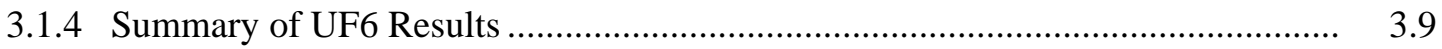

3.1.5 UF6 Release Summary .................................................................................. 3.14

4.0 HF Detection Probabilities for a Specific Test Case .....................................................

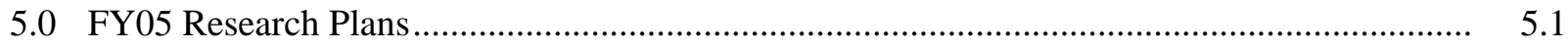




\section{Figures}

3.1 Rapid chemical concentration using a novel On/Off resonance technique

3.2 Comparison of extended 7-day autonomous field tests at PNNL's shipping and Absorbance with receiving warehouse

3.3 Photograph taken of SWIR-CRDS instrument during HF release experiments on the Hanford Site.

3.4 Time series plot showing HF being detecting during release experiments on July 20, $2004 \ldots . . \quad 3.5$

3.5 Time series plot showing HF being detecting during release experiments on July $21,2004 \ldots . \quad 3.6$

3.6 Schematic representation of the indoor UF6 release experiment .................................... 3.7

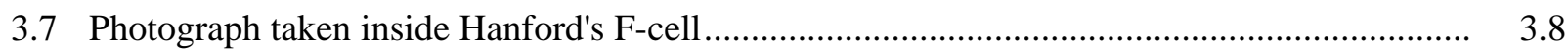

3.8 UF6 release apparatus placed in the F-Cell ........................................................................ 3.8

3.9 Photograph of the SWIR-CRDS instrument during the UF6 release experiment ................... 3.9

3.10 Laboratory HF absorption spectrum taken with the SWIR-CRDS instrument demonstrating 3 ppbv detection sensitivity

3.11 Waterfall plot of HF monitoring during indoor UF6 release

3.12 SWIR-CRDS Inlet loss measurements of HF

4.1 Simulations of downwind HF concentrations from a hypothetical processing facility .

\section{Table}

4.1 Post-scrubbing HF emission factors (mass per unit time) used in this study

4.2 Post-scrubbing HF stack emission density used in this study 



\subsection{Introduction}

Since we presented an extensive introduction to cavity ring down spectroscopy (CRDS) in our FY03 final report, we provide here only a brief description of the technique to re-familiarize the reader. CRDS involves measuring optical loss inside a resonator. The simplest optical resonator is made from two highly reflective mirrors that are aligned to support a single optical mode (i.e., a standing wave), which is commonly called a resonance. If the wavelength of a continuous-wave (cw) laser is coincident with a cavity resonance, light intensity will build up because the cavity has a high-Q factor. If the source is suddenly switched off, or tuned off resonance, the intra-cavity light intensity will gradually decrease due to the slight transmission of each mirror $(<0.1 \%)$ and other diffractive and/or absorptive losses. The decay phenomenon is termed "ring down" as it mimics how the sound from a finely-tuned, or resonant, bell slowly decays after it is struck. Mathematically, this ring down can be expressed as an exponential decay with an associated ring down time constant.

When the cavity is empty the terms governing the temporal evolution of the decay transient can be defined as,

$$
i(t)=i_{o} \exp \left[-(1-R) \frac{t c}{L}\right]
$$

where $\mathrm{c}$ is the speed of light, $\mathrm{R}$ is the mirror reflectivity, $\mathrm{L}$ is the cavity length, and $\mathrm{t}$ is time. The decay time constant (i.e., the time when $i$ equals $1 /$ e of $i_{0}$ ) is given by,

$$
\tau_{\text {empty }}=\frac{L}{c(1-R)}
$$

If an absorbing species is added to the empty cavity, it reduces the ring down time, i.e.

$$
\tau_{\text {total }}=\frac{L}{c[(1-R)+\alpha L]},
$$

where $\alpha$ is the absorption coefficient in units of $\mathrm{cm}^{-1}$. The absorption coefficient is calculated by comparing the ring down times associated with an empty and a filled cavity, i.e.

$$
\alpha=\frac{1}{C}\left[\frac{1}{\tau_{\text {total }}}-\frac{1}{\tau_{\text {empty }}}\right] .
$$

The absorption coefficient is related to the species concentration via $\alpha=\sigma \mathrm{N}$, where $\sigma$ is the molecular absorption cross section in $\mathrm{cm}^{2} /$ molecule and $\mathrm{N}$ is the number density, or concentration, in molecule $/ \mathrm{cm}^{3}$. 



\subsection{Proposed FY04 Milestones}

- 08/30/04 Complete Generation I SWIR CRDS field experiments.

This milestone involves the field testing of the current instrument in more than one scenario. In FY04 this includes: an extended 7-day autonomous sampling test at PNNL's shipping and receiving warehouse, an outdoor HF release experiment on the Hanford Site during the summer of '04, and finally the participation in the indoor $\mathrm{UF}_{6}$ release experiment (monitoring HF levels) at the decommissioned Uranium Recovery Facility on the Hanford Site.

- 08/30/04 Complete a study on cavity noise sources and their influence on CRDS performance.

During FY03 it was found that instrument drift contributed to long term fluctuations in baseline performance. Therefore a milestone was included in the FY04 work scope aimed at understanding the root causes of this and to implement improvements to instrument design and data processing. The reason why long term drift was found to be an issue is in the way molecular absorbance is calculated in CRDS. Essentially molecular absorption is calculated by comparing the total optical loss in the cavity without the molecular absorption to a measurement of the total loss including the molecular absorption. Previously this was done by tuning the laser off resonance and recording a "background" loss value which was subsequently used to compute molecular absorbance. The action was performed every 2-hours during our first field deployment in FY03 and was found to be too long of duration as the instrument baseline wound drift on a shorter timescale. One cause of this was in the way the cavity was being temperature stabilized. An on/off heater control system was being used which caused large swings in local heating and therefore slight cavity misalignment. A proportional system was added in FY04 which greatly reduced these effects. Additionally a modification in the control software now allows the instrument to record a background measurement every 20 seconds, thereby greatly reducing the impact of any additional sources of baseline drift. And finally a detailed study was made estimating the magnitude of intra-cavity Fresnel diffraction on cavity ringdown spectroscopy. It was found that because the instrument is remarkably sensitive to intra-cavity optical loss, Fresnel diffraction (which is normally considered negligible is most optical cavity descriptions) can be a source of drift if there is slight changes in cavity alignment. Fortunately the major source of misalignment was found to be from slow thermal effects which are compensated for by rapid baseline measurement routines now implemented. 



\subsection{FY04 Accomplishments}

In FY04 the SWIR-CRDS instrument conducted 3 field tests. These included an extended (7 day) autonomous run in PNNL's shipping and receiving warehouse, an outdoor hydrogen fluoride release experiment and the indoor UF6 release experiment conducted at Hanford's retired uranium extraction plant. All three tests provided valuable results and added to our insight concerning successful field deployment of a cavity enhanced "point sensor". Additional laboratory work was also completed aimed at understanding the sources of instrument noise. The results of these tests were then used to devise mitigation strategies.

\subsection{Field Tests}

\subsubsection{Second Warehouse Field Test}

During the month of November, 2003 PNNL conducted its second field test of the short-wave infrared cavity ringdown spectrometer (SWIR-CRDS) system (deployed and operated continuously for 7days in PNNL's shipping and receiving warehouse). A detailed description of the instrument can be found in the corresponding FY02 \& FY03 final reports for the project. In brief, the instrument has been designed to measure very weak absorption due to the presence of analyte species within an optical cavity. At the time of the test, PNNL's SWIR-CRDS instrument was configured to detect ammonia $\left(\mathrm{NH}_{3}\right)$ as the test species (detected at a wavelength of $1531.7 \mathrm{~nm}$ ). Several changes had been implemented to the instrument since the first field test which have resulted in a notable improvement in performance. Based on these latest results our estimate for the ammonia detection limit is 375 ppb $_{\mathrm{v}}$ (@50 Torr sample cell pressure with data generated at a rate of $1 \mathrm{~Hz}$ ). Improvements to the system included adding a novel baseline measurement scheme, improvement in detected signal amplitude and longer ringdown times.

One significant attribute of the instrument is its ability to make near real-time measurements of absolute ammonia concentration. Under typical operation absolute concentration and mixing ratio (i.e., $\mathrm{ppm}_{\mathrm{v}}$ ) are ascertained at a rate of 1-3 measurements per second. In order to accomplish this a "baseline" measurement of optical loss must be made which is then used to compute absolute optical loss (needed for the calculation of analyte concentration). For the SWIR-CRDS system baseline measurements can be made in different ways. One way of obtaining this information is to measure optical loss of a sample with no analyte present (this is accomplished using a gas mixture known to have zero concentration of ammonia). Unfortunately this approach is time consuming (typically 2-4 minutes) requiring the gas handling system to switch over from ambient air sampling to a test mixture and back again. A second approach to making a baseline measurement is to tune the probe laser to a wavelength which is not absorbed by the target analyte without switching over to a test mixture. This second approach is schematically shown in Figure 3.1. 
During this field deployment the laser is tuned to the peak of the ammonia absorption feature during $75 \%$ of the measurements ( 20 concentration measurements taking 20 seconds). After 20 "on-peak" measurements the software algorithm tunes the laser "off-peak" and a baseline ringdown measurement is acquired. The laser is then tuned back to the peak of the feature and a sequence of measurements are taken which, when combined with the most recent baseline measurement, are used to estimate analyte concentration. During the first field deployment, baseline measurements were acquired only once every 120 minutes, now they are acquired every 20 seconds. Sensitivity to long-term instrument drift is dramatically reduced following this approach.

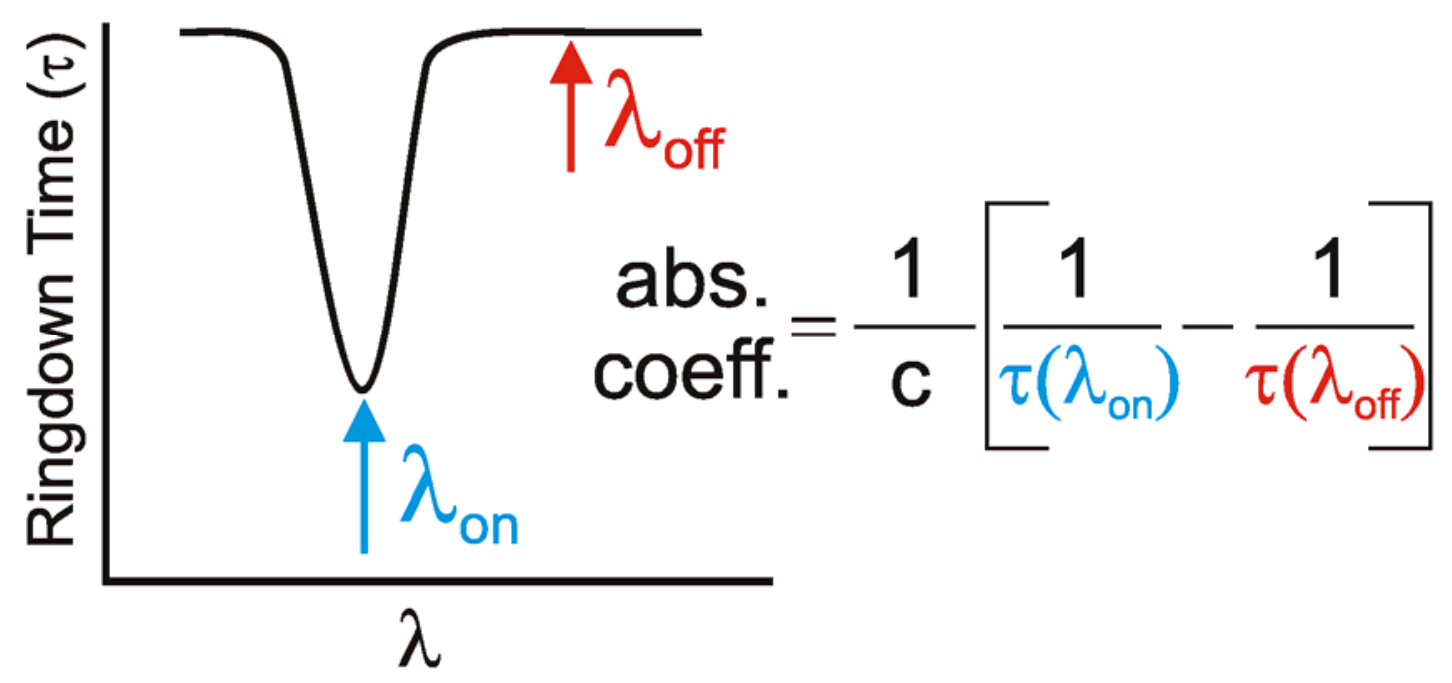

Figure 3.1 Depicts how on- and off-resonance measurements are used to compute the absorption coefficient (and thereby concentration).

Additional improvements made to the instrument included an improved optical arrangement which produced an increase in detected cavity transmission and longer ringdown times resulting in higher signal to noise on the primary data (i.e., the ringdown transient itself). A comparison of our first and second field deployments is shown in Figure 3.2. As expected we did not observe ammonia in the warehouse (at least to our detection limit) due to ammonia's low level in typical environments $\left(<10 \mathrm{ppb}_{\mathrm{v}}\right)$. On the final day of the test we exposed the instrument to low levels of ammonia vapor (from an aqueous ammonia solution). Closer analysis of the exposure data showed that the vapor transit time through the instrument is approximately 3 seconds, indicating a good match between the data acquisition rate and gas throughput rate. Statistical analysis of the data shown in Figure 3.2 suggest an improvement of roughly a factor of 4 in both accuracy and precision in the background signal between the two field tests. 
This field test has helped us in confirming our approach to improving the instrument performance (lowest possible detection limit in the shortest amount of integration/sampling time).

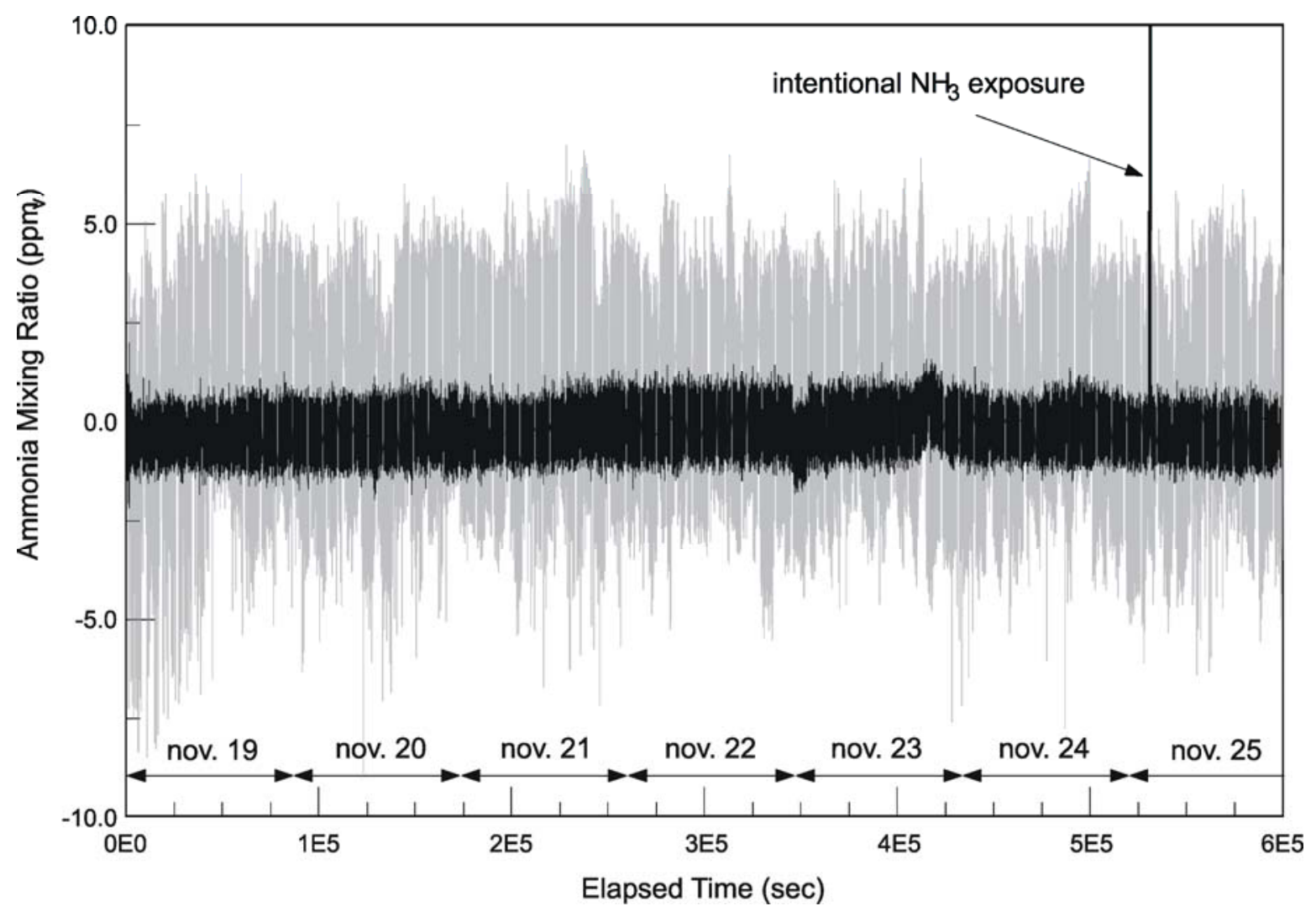

Figure 3.2 Comparison of test results from two 7-day field trials of PNNL's SWIR-CRDS instrument. The gray trace is from the first trial (Summer '03) while the black trace is from the second trial (Nov. '03). The instrument was configured for autonomous ammonia monitoring.

\subsubsection{Outdoor HF Release Test}

Between July 18-21 PNNL's SWIR-CRDS instrument participated in an outdoor chemical release experiment at the old Hanford Townsite on DOE's Hanford Site. The chemical used for this test was hydrogen fluoride. In order for the instrument to detect HF the system needed to be modified to operate at $1272.98 \mathrm{~nm}$ (to detect the $\mathrm{R}(0)$ second vibrational overtone). Changes included swapping in a new laser head which operates from 1270-1325 nm and replacing the existing high reflecting mirrors with ones optimized for the new wavelength. Once these changes were accomplished laboratory tests were conducted in order to determine the instrument's lower HF detect limit. This was found to be $\sim 1 \mathrm{ppb}_{\mathrm{v}}$ when the operating pressure of the instrument was maintained near 350 Torr. The reason for the marked improvement in detection limit for HF compared to that of ammonia ( $\left.350 \mathrm{ppb}_{\mathrm{v}}\right)$ is the larger linestrength for the HF transition probed at 1272.98 compared to the linestrength for ammonia probed at 
$1531.7 \mathrm{~nm}$. Also operating at higher pressure improves the sensitivity of the instrument as the spectral width of the absorption features is pressure broadened thereby providing additional data points for the fitting routines.

For the field tests the instrument was housed in the back of a rental moving truck and kept on the site of the release for the week. A small 5000 BTU single room air conditioner was used to provide instrument cooling during the test (as temperatures exceeded $100^{\circ} \mathrm{F}$ in the back of the truck during the day). Power was provided by a standard $10 \mathrm{kWatt}$ generator, this size was overkill for our application. Despite the high temperatures and less than "clean" electrical power the instrument performed very well. The instrument required no realignment after transport and cleanly started up each day during the test, requiring less than 30 minutes before tests were conducted. Figure 3.3 is a photograph taken on July $20^{\text {th }}$, 2004 during the second day of the outdoor HF release.

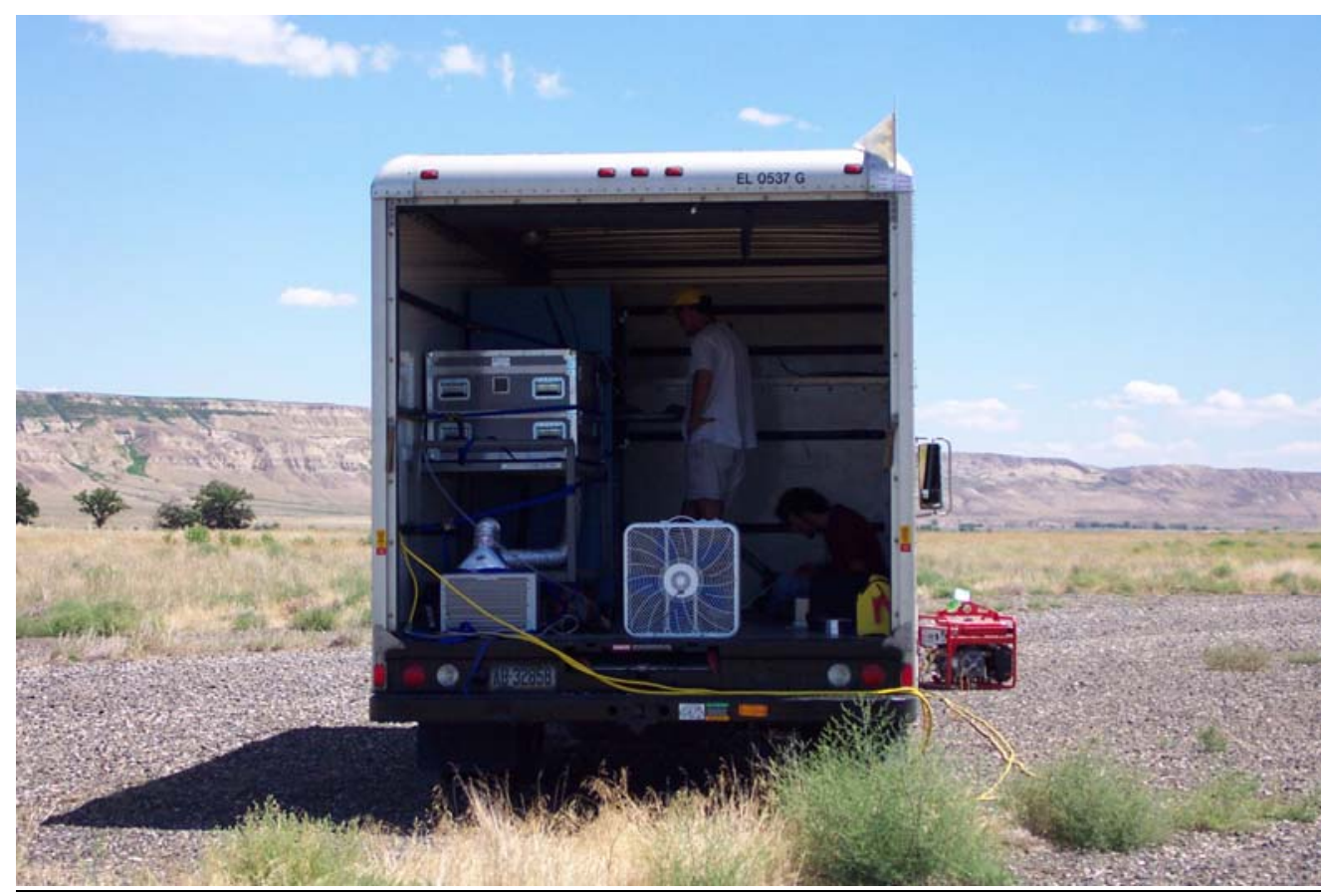

Figure 3.3 Photograph of the SWIR-CRDS instrument during the outdoor HF release experiments during July of 2004. The instrument crate can be seen against the left wall of the moving van.

The inlet to the instrument consisted of a 4-foot section of $1 / 2$ " OD polyethylene tubing attached to the exterior of the vehicle. Because the HF was significantly diluted prior to release $\left(<10 \mathrm{ppm}_{\mathrm{v}}\right)$ the instrument was kept close the release point $(<20$ meters). Unlike during the ammonia tests the SWIRCRDS did not utilize the on/off resonance data acquisition mode. Rather the instrument was configured to record short wavelength scans $(0.3 \mathrm{~nm}$ around $1272.98 \mathrm{~nm})$. The reason for this is that it is quite difficult to maintain HF in a reference gas cell for an extended period of time due to its reactivity with most materials. Without a good HF reference the on/off resonance technique cannot be implemented. The wavelength scans can be seen in the data (Figure 3.4) for July $20^{\text {th }}$ in which three HF releases occurred, separated by roughly 1 hour. HF is clearly detected during the second release. Absorption features for oxygen and water are continuously observed by the instrument within each wavelength scan 
which takes approximately 95 seconds to complete. On July $21^{\text {st }}$ six HF releases occurred, of which 3 were easily detected by the instrument as seen in Figure 3.5. During both of these releases the wind speed and direction often changed resulting in the release plume drifting away from our inlet sampling tube.

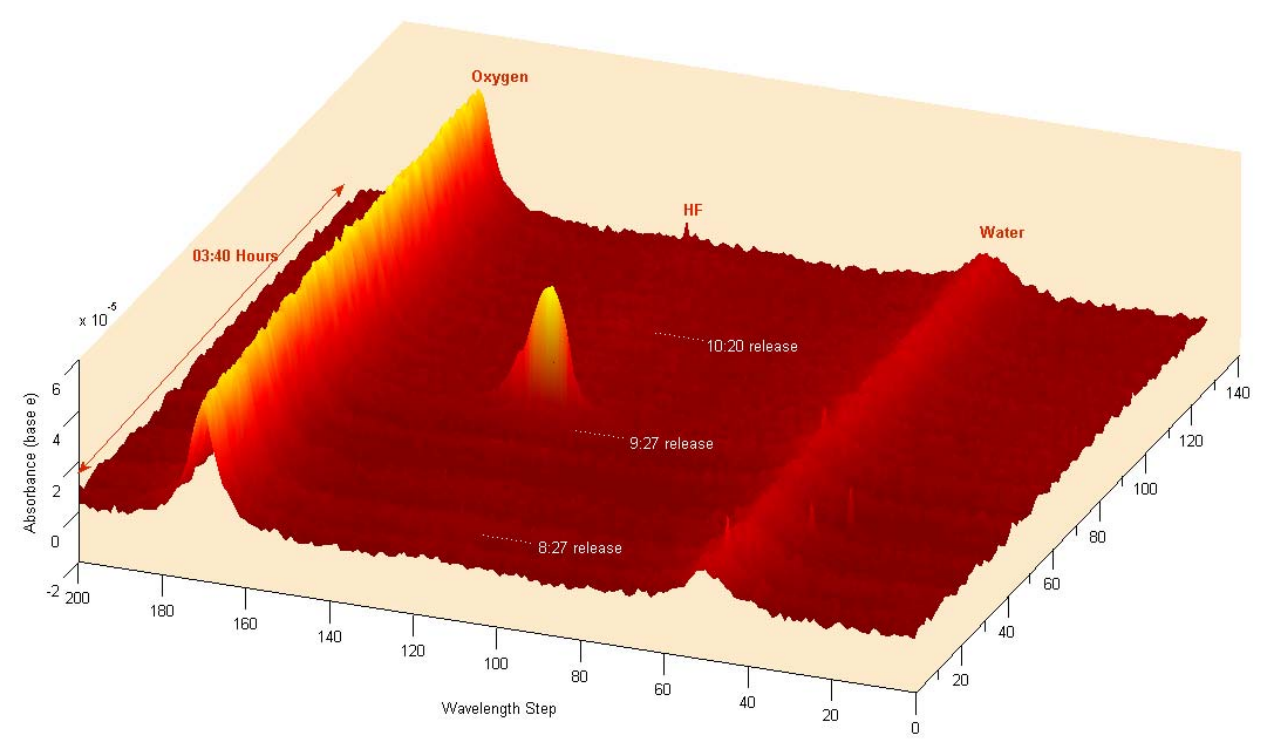

Figure 3.4 A time series waterfall plot of the instrument's response to $3 \mathrm{HF}$ releases during the July $20^{\text {th }}$ HF release. The $\mathrm{R}(0)$ line of HF was clearly detected at $1272.98 \mathrm{~nm}$ during the second release. The wind direction was not favorable for the $1^{\text {st }}$ and $3^{\text {rd }}$ releases. 


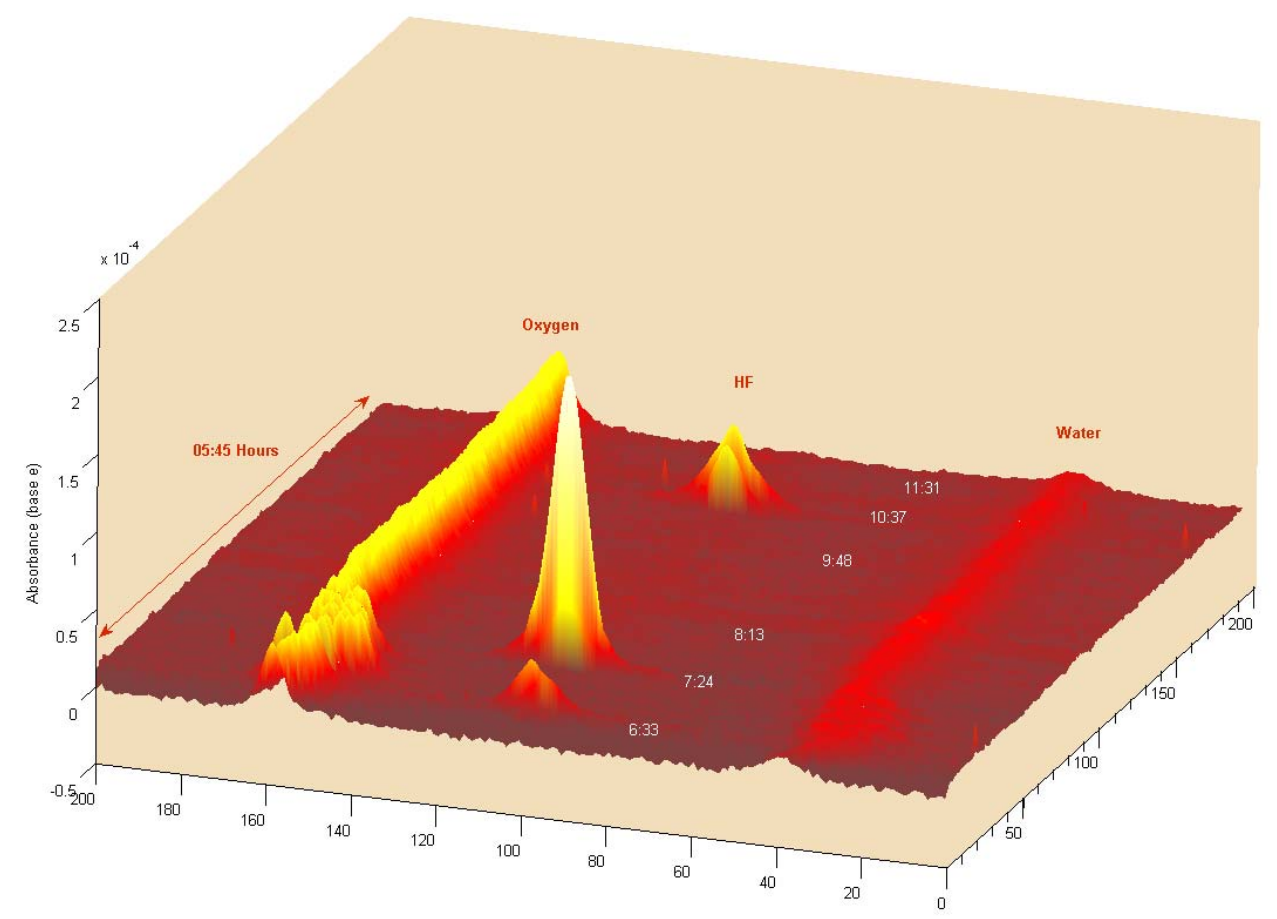

Figure 3.5 A time series waterfall plot of the instrument's response to $6 \mathrm{HF}$ releases during the July $21^{\text {st }}$ HF release. The $\mathrm{R}(0)$ line of HF was clearly detected during the 3 of the releases. The largest peak seen here is consistent with $\sim 100 \mathrm{ppb}_{\mathrm{v}} \mathrm{HF}$.

\subsubsection{U-Plant UF6 Release Test}

PNNL's SWIR CRDS instrument participated in a UF6 release experiment on Monday, Aug. $30^{\text {th }}$, 2004. One gram of $19 \%$ enriched UF6 was released into the previously contaminated F-Cell at Hanford's U-Plant over a period of one hour, a box fan mixed the air in room during and after the release. This facility was previously used for calcining Uranium as part of Hanford's uranium recovery program which ceased operations in 1992. The cavity ringdown instrument used for this test was configured for continuous air sampling and monitoring of hydrogen fluoride (HF). HF is the hydrolysis product of UF6 in ambient air. Laboratory measurements prior to the release gave a lower detection limit for HF at slightly below $1 \mathrm{ppbv}$ (with an operating pressure of 0.7 atmosphere (530 Torr)). Because the F-Cell is radiation contaminated room a 100 foot $1 / 2$ " diameter polyethylene tube fitted with 6 PTFE filters was required to deliver a continuous air stream to the area where the instrument was housed. Both polyethylene and PTFE (teflon) have excellent compatibility with HF. The exhaust gas from the instrument was delivered back into the F-Cell by a similar tube. Figure 3.6 shows a schematic representation of the instrument location with respect to the F-Cell. The instrument recorded a small wavelength spectrum every 45 seconds that overlaps a spectral region where HF absorbs near 1272.98 $\mathrm{nm}$. Given the approximate volume of the F-Cell and the amount of material released the theoretical maximum HF mixing ratio would have been 80 parts per billion assuming all the HF stayed in the vapor 
phase and did not react with ambient chemicals or the various surfaces. During the entire release and for 12 hours post release the cavity ringdown instrument did not register HF. This result is not surprising given the extremely high probability that HF would react with the myriad of surfaces present in this industrial environment. HF reacts quickly with most inorganic solids containing calcium and silicon dioxide, two very common materials found in dust and exposed concrete (both of which were very plentiful). Additionally, HF is used to etch metals and remove rust. Much of the piping, pumps and structures in the F-cell showed signs of rusting (where the paint had chipped off).

\section{Hanford U-plant UF6 Release}

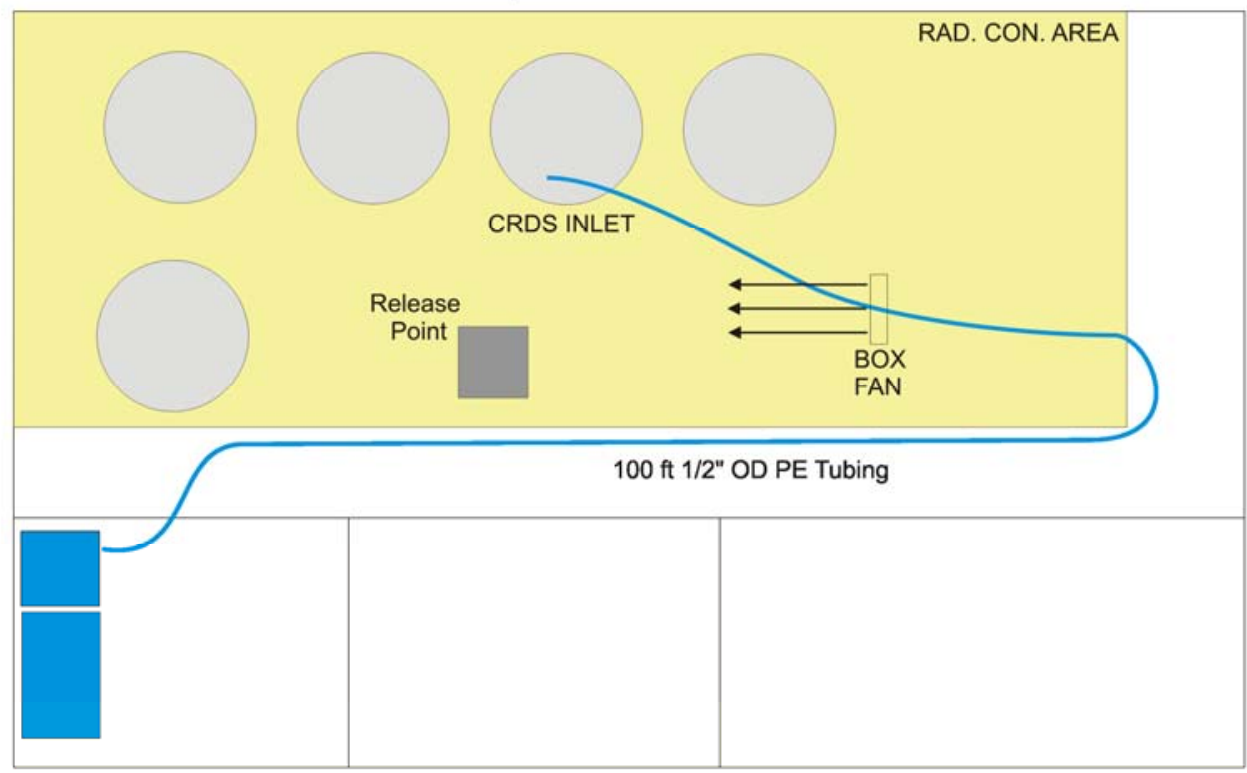

\section{CRDS System}

Figure 3.6 Schematic layout of the F-Cell at Hanford's retired uranium recovery plant. The area shown in yellow represents the contaminated area.

Figure 3.7 is a photograph of one of the several calciners within the F-Cell. The aluminum foil is part of another experiment which took place during the test. This figure is meant to show the condition of the room (note the rust, dust and exposed metal surfaces). The UF6 release apparatus was provided by Oak Ridge National Laboratory and is shown in Figure 3.8. 


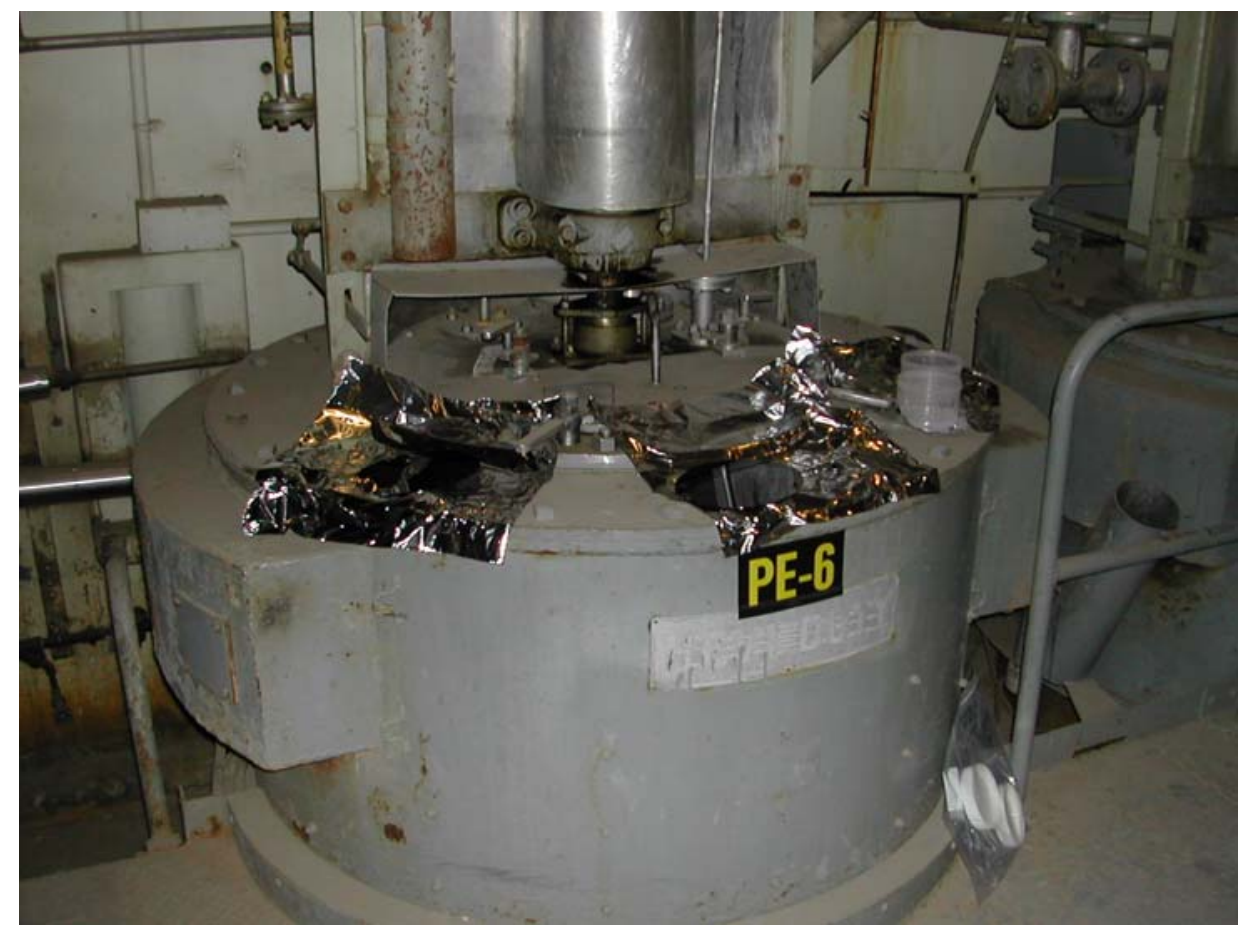

Figure 3.7 Photograph of industrial equipment taken inside the F-Cell.

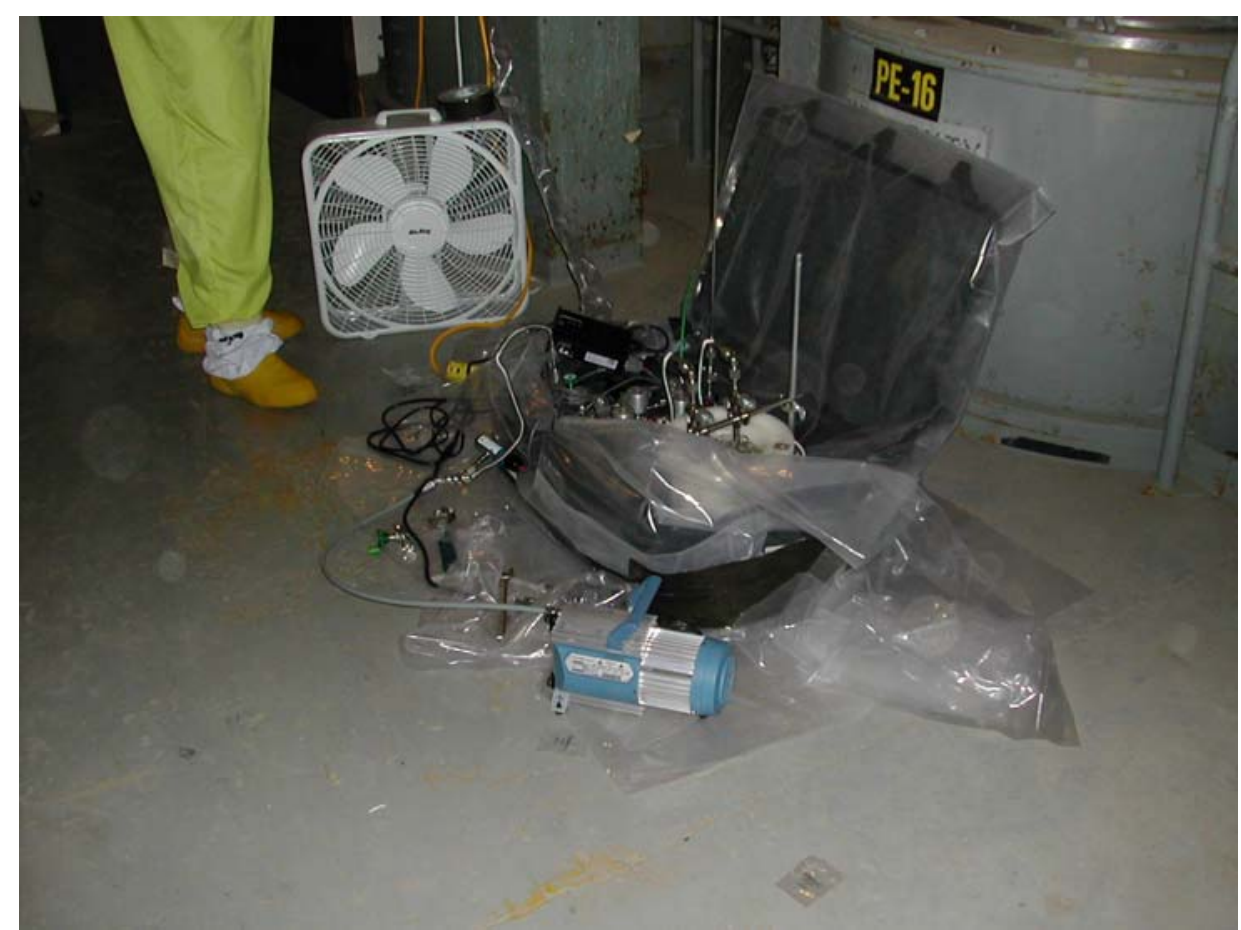

Figure 3.8 Photograph of UF6 release apparatus inside the F-Cell. 
The UF6 release apparatus shown in Figure 3.8 was developed by Oak Ridge National Laboratory. It released 1 gram of UF6 over a one hour period from a $1 / 4$ " OD stainless steel tube which was approximately 18 " from the floor of the room. A white "smoke-like" plume (presumably $\mathrm{UO}_{2} \mathrm{~F}_{2}$ ) could be seen just moments after the release commenced but quickly dispersed and was difficult to see again during the rest of the one hour release. A small box fan was used to mix the air within the sealed room (the fan can be seen in Fig. 3.8). The inlet to the SWIR-CRDS sampling tube was approximately 12' away from the release point at an elevation of approximately 48 " off the floor. The fan blew the release products away from the inlet tube. Figure 3.9 shows a photograph taken of the SWIR-CRDS instrument housed in a former office room near the F-Cell.

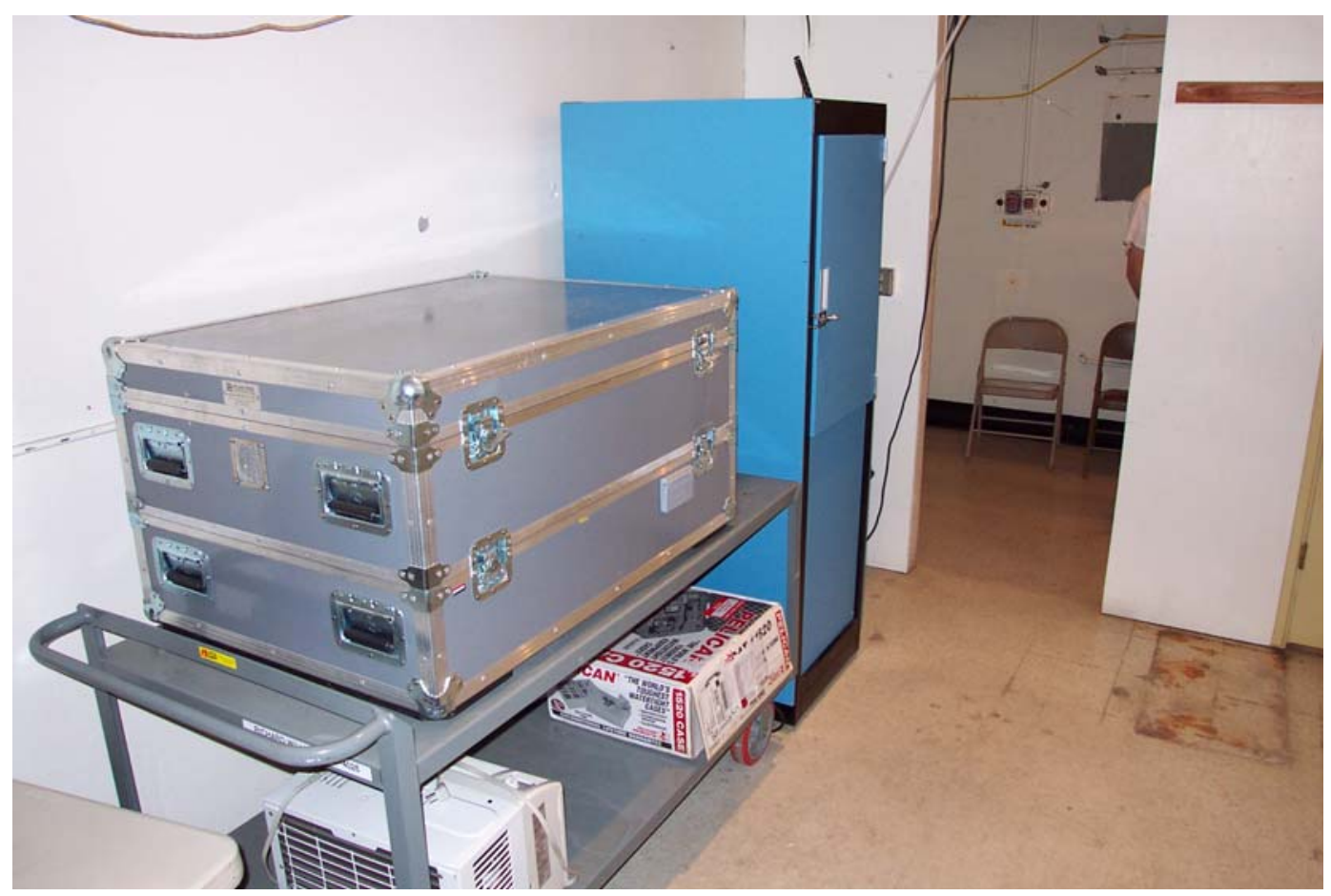

Figure 3.9 Photograph of the SWIR-CRDS instrument during the UF6 release. The instrument had to be located in a non-contaminated area near the F-Cell. The gray crate is the optical bench and blue instrument rack contains the support electronics and vacuum pump.

\subsubsection{Summary of UF6 Results}

On Aug. 30, 2004 one gram of UF6 was released into the F-Cell at the Uranium Processing Facility. The material was released over a 1-hour period at an non-constant rate (the rate of release decreased nearly exponentially during the 60 minutes). The static air in the F-Cell room was thoroughly mixed using a standard box fan. Previous measurements using SF6 as a tracer gas confirmed that the air in the F-Cell did not mix with outside air (the room's HVAC system was not enabled). Based on the approximate volume of the room $\left(6800 \mathrm{~m}^{3}\right)$ and complete hydrolysis of UF6 (i.e., 4 HF's produced per $\mathrm{UF}_{6}$ during conversion to $\mathrm{UO}_{2} \mathrm{~F}_{2}$ ) a maximum concentration of $\mathrm{HF}$ in the room would have been $35 \mu \mathrm{g} / \mathrm{m}^{3}$ $\left(\right.$ or $\sim 40 \mathrm{ppb}_{\mathrm{v}}$ ). This assumes the HF does not react with ambient chemicals present in the air and that the HF does not react or stick to ambient surfaces. 
Figures 3.7 and 3.8 above are representative of the environment inside the F-Cell which contains several of the large calciners and other chemical process equipment. Because the environment is a radiation contamination area only trained personnel were allowed in and most equipment that went in was subsequently treated as contaminated waste or potentially contaminated waste and needed to be cleaned thoroughly before being allowed to leave (after certification). Because of the high potential for radiation contamination the SWIR CRDS instrument was staged outside the F-Cell. Continuous air samples were drawn into the instrument through a new 100 foot section of $1 / 2$ " OD (3/8" ID) polyethylene tube. The exhaust from the vacuum pump was returned to the F-Cell via another section of similar tubing. The inlet of the tubing in the F-Cell was fitted with two filter cartridges in series to remove particulates of highly enriched uranium. The inlet was 10-15 feet away from the release point and not down-wind from the fan flow. Two additional disposable filters were placed at the outlet of the sampling line and just prior to the instrument's own filters (for a total of 6 filters). This was the minimum allowed by the radiation safety personnel for the test to prevent contamination and/or a spread of contamination. All filters were Teflon (PTFE) based housed in either plastic or stainless steel housings. At the time of the test the instrument's limit of detection for HF in the sample cavity was 3-5 $\mathrm{ppb}_{\mathrm{v}}$ (as seen by a pretest data set shown in Figure 3.10). As in the outdoor HF release experiment a short wavelength scan centered around the HF absorption feature at $1272.98 \mathrm{~nm}$ was performed in which both oxygen and water are also observe. These scans were recorded at a rate of one scan every 2 minutes. During the release on August $30^{\text {th }}$ and for nearly one day after the release the instrument registered no detectable HF. 


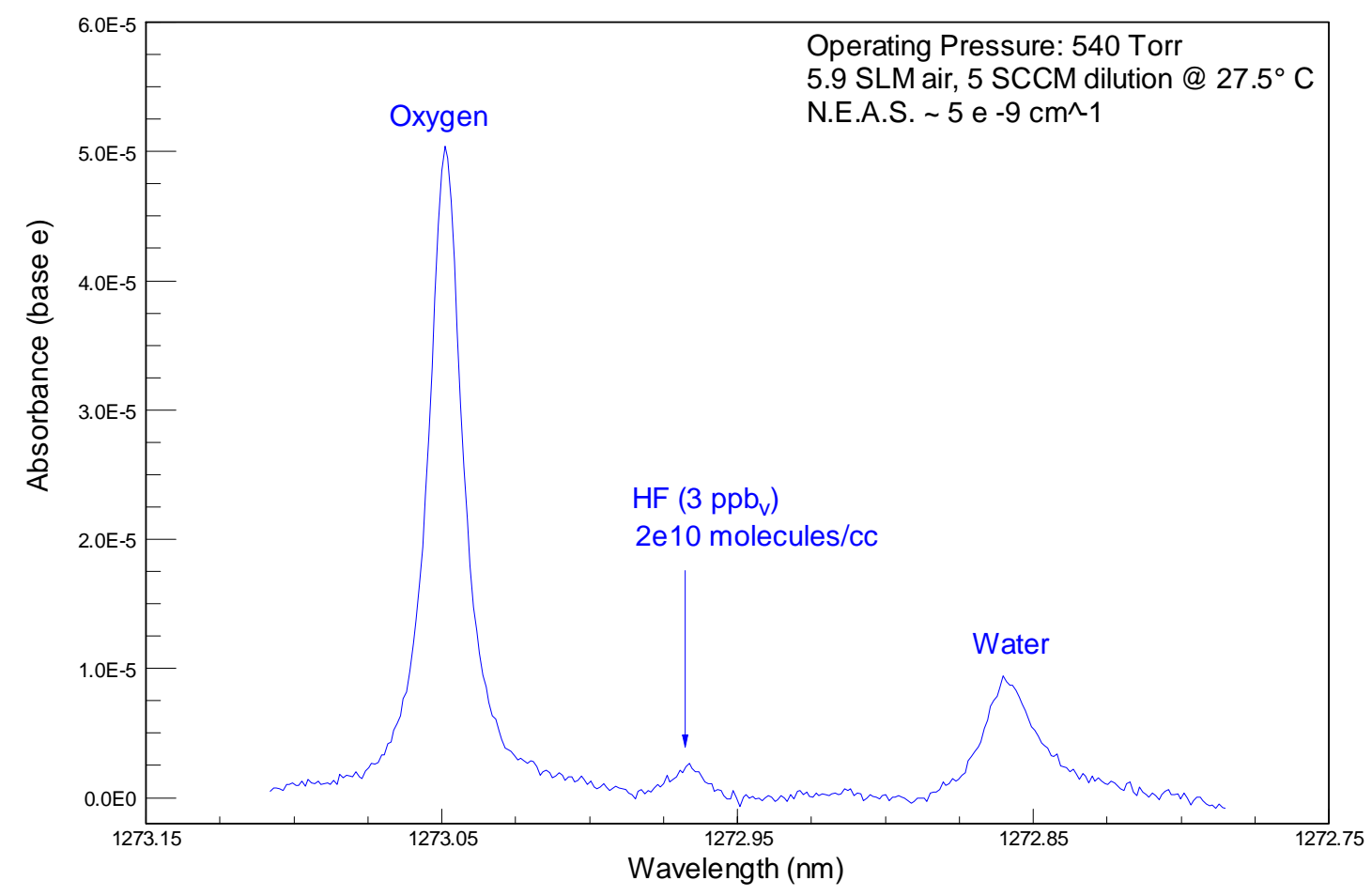

Figure 3.10 Absorption spectrum of a trace sample of HF mixed with ambient air showing the signal to noise of a $3 \mathrm{ppb}_{\mathrm{v}} \mathrm{HF}$ sample. This is the same spectral region scanned for both the outdoor HF release as well as the indoor UF6 release.

Figure 3.11 shows a waterfall plot of the actual absorption spectra recorded during the UF6 release period. The two peaks shown are oxygen (on the left) and water (on the right). The center wavelength of the spectra is $1272.98 \mathrm{~nm}$ and spans roughly $0.3 \mathrm{~nm}$. The release commenced near scan 20 and ended near scan 50. If HF had been detected it would have in the region between the two absorption peaks (as in Figures 3.4, 3.5 and 3.10). A slight wavelength adjustment was performed during the release and results in the offset in the water peak about half way through the run. 


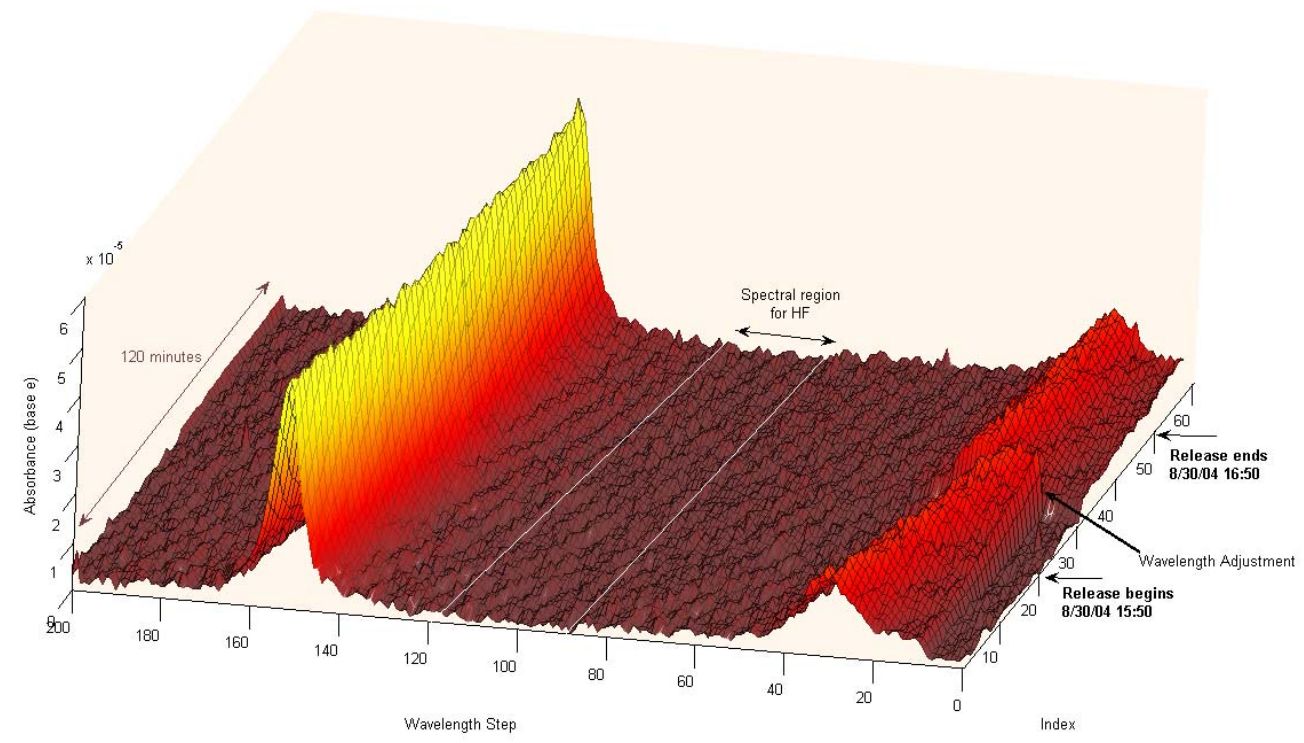

Figure 3.11 Raw wavelength scans centered at the HF R(0) transition at $1272.98 \mathrm{~nm}$ taken during the UF6 release. The two parallel white lines indicate the region where HF absorbs. The detection limit for HF in the sampling cavity during these tests was $<3 \mathrm{ppb}_{\mathrm{v}}$.

At the conclusion of the test one outstanding question remained, "could reaction and/or retention of HF in the sampling line and/or filters account for a reduction in HF concentration below the detection limit of the instrument?" To answer this question a laboratory experiment was performed where a similar length of polyethylene tubing (with the addition of filters) was placed between the CRDS instrument and trace HF generator. Measurements of HF concentration were taken before adding the tubing and before adding the filters. Room air (usually containing $1-2 \%$ water) was used as a dilutant in all cases to reproduce the actual F-Cell release (standing water was present in the F-Cell during the release). A permeation device was used to generate a constant flow of 50-60 ppb $\mathrm{v}_{\mathrm{v}} \mathrm{HF}$ in room air at flow rates of 1.1 SLM (standard liters per minute). The results of the test are shown in Figure 3.12 below. The addition of the 100' coil produced an immediate drop in the detected HF level (from 50 to $27 \mathrm{ppb}_{\mathrm{v}}$ ) which took more than 24 hours of continuous exposure to recover to the $50 \mathrm{ppb}_{\mathrm{v}}$ level. Once the inlet tube was sufficiently passivated 4 filters were added between the coil and the CRDS instrument. At the time of this test additional filters were requested from Hanford crafts-services (who installed them at the U-Plant) but they had not arrived. Of the 4 filters used in this test 2 were the stainless steel housing type and one was the plastic housing type fitted with 2 filter elements (all had Teflon filter material). These filters produced an average HF loss of $11 \mathrm{ppb}_{\mathrm{v}}$ which is fairly constant in time. From these tests it is reasonable to say that if $50 \mathrm{ppb}_{\mathrm{v}} \mathrm{HF}$ were present at the inlet of the filters in the F-Cell after the release of UF6 then the maximum signal the instrument would have registered would have been $16 \mathrm{ppb}_{\mathrm{v}}(50-27-11=16$ $\mathrm{ppb}_{\mathrm{v}}$ ). Conversely, if the instrument had registered $16 \mathrm{ppb}_{\mathrm{v}} \mathrm{HF}$ the actual mixing ratio in the F-Cell would have been at least $50 \mathrm{ppb}_{\mathrm{v}}$. Because no HF signal was observed above the minimum detectable limit it is also appropriate to say that HF was not present at levels in excess of 43 ppb $_{\mathbf{v}}$ near the instrument's inlet in the F-Cell during the release (minimum detection limit $\left[5 \mathrm{ppb}_{\mathrm{v}}\right]_{+}$ filter losses $\left[11 \mathrm{ppb}_{\mathrm{v}}\right]+$ unpassivated tubing losses $\left[27 \mathrm{ppb}_{\mathrm{v}}\right]=43 \mathrm{ppb}_{\mathrm{v}}$ L. 


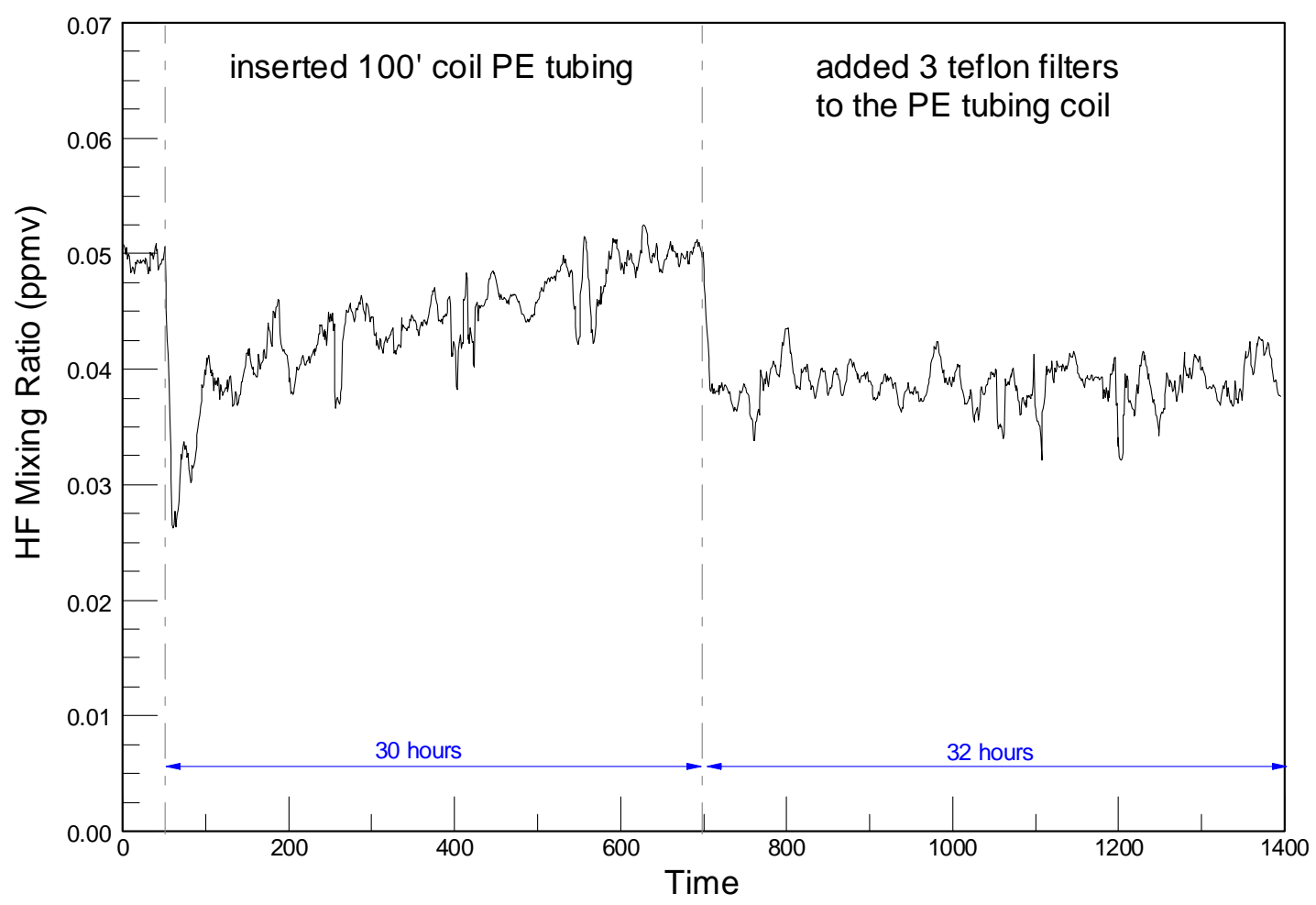

Figure 3.12 Post UF6 release laboratory measurements made with the SWIR-CRDS instrument to determine inlet HF losses. Virgin polyethylene tubing retains HF until passivated, while Teflon filter material seems to act as a reactive matrix consuming HF which passes through it.

The modified detection limit of $43 \mathrm{ppb}_{\mathrm{v}} \mathrm{HF}$ is very close to the theoretical maximum mixing ratio of $\sim 35 \mathrm{ppb}_{\mathrm{v}} \mathrm{HF}$ for the release in the F-Cell. Possible "sinks" for HF in the F-Cell include:

- reaction or binding with water vapor

- absorption and solvation in water aerosols

- absorption/reaction on solid surfaces (paint, metal oxides, concrete, mineral dust and aerosols)

- remains complexed with the hydrated uranium oxide particles.

It is most likely that HF is indeed removed quickly from the air. This suggestion is supported by results of PNNL's FM-DIAL instrument which participated in the separate tent release of UF6 which clearly demonstrated that HF was consumed as fast as it was being generated (see FY04 FM-DIAL annual report). These tests measured HF only inches above the UF6 release tube, not 10-15 feet away as in the CRDS test in the F-Cell. 


\subsubsection{UF6 Release Summary}

In summary, if all the UF6 released during the test had been converted to HF and none of it was irreversibly lost through reactions or adsorption then the HF levels in sampling cavity would have been just at or below the detection limit of the instrument. A significant observation was made by PNNL's other HF detection experiment conducted during the tent UF6 release in which it was found that there are indeed large irreversible sinks for HF. Therefore, based on these observations it is highly unlikely that under any circumstance (even substantially lower detection limits) HF would have been detected under the testing conditions. 


\subsection{HF Detection Probabilities for a Specific Test Case}

Scenario: What would be the necessary HF detection limit for an instrument placed $1 \mathrm{~km}$ from a processing facility which releases $1 \mathrm{~kg}$ of $\mathrm{HF} /$ year?

Summary Conclusion: For a processing facility releasing $1 \mathrm{~kg}$ of $\mathrm{HF} /$ year (a large amount) it would be extremely difficult to detect $\mathrm{HF}$ at distances approaching $1 \mathrm{~km}$ without a detection limit near 1 partper-trillion.

It is anticipated that very low levels of HF may be emitted into the atmosphere from a gas-centrifuge enrichment facility during normal handling/processing of input LEU and/or output HEU (both of which are in the chemical form of $\mathrm{UF}_{6}$ ). Upon release into ambient air gaseous $\mathrm{UF}_{6}$ undergoes hydrolysis to produce fine $\mathrm{UO}_{2} \mathrm{~F}_{2}$ particulates and $\mathrm{HF}$ vapor given by the following reaction pathway

$$
\mathrm{UF}_{6}(\mathrm{~g})+2 \mathrm{H}_{2} \mathrm{O}(\mathrm{g}) \rightarrow \mathrm{UO}_{2} \mathrm{~F}_{2}(\mathrm{~s})+4 \mathrm{HF}(\mathrm{g})
$$

Additionally, accidental releases of $\mathrm{UF}_{6}$ may occur resulting in short duration spikes in $\mathrm{HF}$ concentrations. Western environmental standards require the use of sophisticated scrubbing equipment consisting of activated charcoal filters and alumina beds for reducing $\mathrm{UO}_{2} \mathrm{~F}_{2}$ and $\mathrm{HF}$ levels, respectively in enrichment facilities designated for producing power plant reactor grade material.

In order to gauge the probability of detecting HF emitted from such a facility a simple first-order calculation has been performed. A range of annual output levels have been included. A simple Gaussian dispersal model (http://www.ess.co.at/AIR-EIA/LECTURES/L001.html ) is used to compute the ground level HF concentrations at 1,5 and $10 \mathrm{~km}$ from the stack. A description of the model is given below. A 0 $\mathrm{km}$ data point is also included and is referenced to the actual stack opening, not ground level. Atmospheric condition is kept stable, i.e., the least amount of mixing on the Pasquill scale (a scale used to describe atmospheric mixing), increasing the mixing would lower the expected HF concentrations. Table 4.1 lists the ranges of HF emissions for this study, in three useful units.

\begin{tabular}{|l|l|l|}
\hline grams HF/year & grams HF/min. & HF molecules/min. \\
\hline 0.1 & $1.9 \mathrm{e}-7$ & $5.8 \mathrm{e} 15$ \\
\hline 0.5 & $9.5 \mathrm{e}-7$ & $2.9 \mathrm{e} 16$ \\
\hline 1 & $1.9 \mathrm{e}-6$ & $5.8 \mathrm{e} 16$ \\
\hline 10 & $1.9 \mathrm{e}-5$ & $5.8 \mathrm{e} 17$ \\
\hline 100 & $1.9 \mathrm{e}-4$ & $5.8 \mathrm{e} 18$ \\
\hline 1000 & $1.9 \mathrm{e}-3$ & $5.8 \mathrm{e} 19$ \\
\hline
\end{tabular}

Table 4.1 Post-scrubbing HF emission factors (mass per unit time) used in this study. 
Source density $\left(\mathrm{mg} / \mathrm{m}^{3}\right)$ can be a requirement for gas dispersion models, therefore it is required to convert the absolute mass released per unit time to a density, these values are presented in Table 4.2. In order to compute density some assumption about the facility effluent scrubbing system needs to be made. A generally accepted ventilation rate for maintaining worker safety ranges from 0.3 to 30 complete air exchanges per hour ["The effect of room size and general ventilation on the relationship between near and far-field concentrations", JW Cherrie in Appl. Occup. Environ. Hyg. 1999 Aug;14(8):539-46]. Assuming a low priority placed on worker safety (i.e., 0.1 room volume exchanges per hour) and a small footprint facility $\left(2800 \mathrm{~m}^{3}\right)$ a ventilation system exchanging $4.7 \mathrm{~m}^{3} / \mathrm{min}$ would be required. This allows the mass flow to be converted into HF density at the stack.

\begin{tabular}{|l|l|l|l|}
\hline grams HF/year & grams HF/sec & $\begin{array}{l}\text { Source HF density } \\
(\mathrm{mg} / \mathrm{m} 3)\end{array}$ & $\begin{array}{l}\text { Source HF mixing } \\
\text { ratio }\left(\mathrm{ppb}_{\mathrm{v}}\right)^{\mathrm{a}}\end{array}$ \\
\hline 0.1 & $3.2 \mathrm{e}-9$ & $4.0 \mathrm{e}-5$ & 0.065 \\
\hline 0.5 & $1.6 \mathrm{e}-8$ & $2.0 \mathrm{e}-4$ & 0.325 \\
\hline 1 & $3.2 \mathrm{e}-8$ & $4.0 \mathrm{e}-4$ & 0.650 \\
\hline 10 & $3.2 \mathrm{e}-7$ & $4.0 \mathrm{e}-3$ & 6.50 \\
\hline 100 & $3.2 \mathrm{e}-6$ & $4.0 \mathrm{e}-2$ & 65.0 \\
\hline 1000 & $3.2 \mathrm{e}-5$ & $4.0 \mathrm{e}-1$ & 650 \\
\hline
\end{tabular}

Table 4.2 Post-scrubbing HF stack emission density used in this study.

a) assuming stack content is only slightly above atmospheric pressure.

Gas Dispersion Parameters:

Wind Speed:

Air Temperature:

Exit Temperature:

Stack Diameter:

Stack Height:

Exit Velocity:
$2 \mathrm{~m} / \mathrm{sec}(4.5 \mathrm{mph})$

$20 \mathrm{C}$

$20 \mathrm{C}$

1 meter

10 meters

$1 \mathrm{~m} / \mathrm{sec}$

For the above parameters, plume dispersion was simulated. The results are presented in Figure 4.1 as a function of distance from the stack. The HF mixing ratio is computed at ground-level at the specified distance from the stack in the downwind direction (except for the $0 \mathrm{~km}$ distance which represents the source term at the stack opening). No assumptions have been made concerning the chemical reactivity or fate of HF in the atmosphere. It is most likely that some fraction of the HF will bind with the large amounts of water present in the atmosphere $\left(\mathrm{HF}-\mathrm{H}_{2} \mathrm{O}\right.$ binding energy is $9 \mathrm{kcal} / \mathrm{mole}$, well above thermal energies). The mole fraction of HF which is bound to water has not been calculated here since this is a detailed calculation. While HF is a strong aqueous acid it is thermodynamically stable with a strong H-F bond. Water aerosols in the air will also represent a "sink" for HF molecules; as HF is readily dissolved in an aqueous media.

Decreasing the atmospheric stability (from the most stable atmosphere in this calculation) will increase the amount of mixing resulting in even lower mixing ratio's downwind from the stack. Therefore the numbers shown in Figure 4.1 are somewhat of an upper-limit or best-case scenario. Based 
on these results a HF sensor with a detection limit of 10 parts per trillion would be necessary to detect HF at ground level $1 \mathrm{~km}$ away from the stack under ideal atmospheric conditions, assuming the facility emitted HF steadily at a rate of $1 \mathrm{~kg} /$ year.

Several important factors could influence this conclusion. First, there are no "sinks" for HF included in this calculation. There will most likely be physicochemical pathways which reduce HF as it propagates through the atmosphere. Second, turbulent mixing is minimal under the current model. Increased mixing will cause further dilution of HF making it harder to detect. One possible up-shot is that the calculations were done for ground level modeling. Plume dynamics are complex; depending on the exact conditions of the release (temperature, stack height, exit velocity, gas composition, etc.) a plume can be fairly buoyant resulting in higher above ground concentrations or a plume can settle to the ground if its density is higher than that of the surrounding air. If the plume is buoyant then an airborne sampling system (at the proper distance from the stack) may probe air that has a higher concentration of HF than that found at ground level.

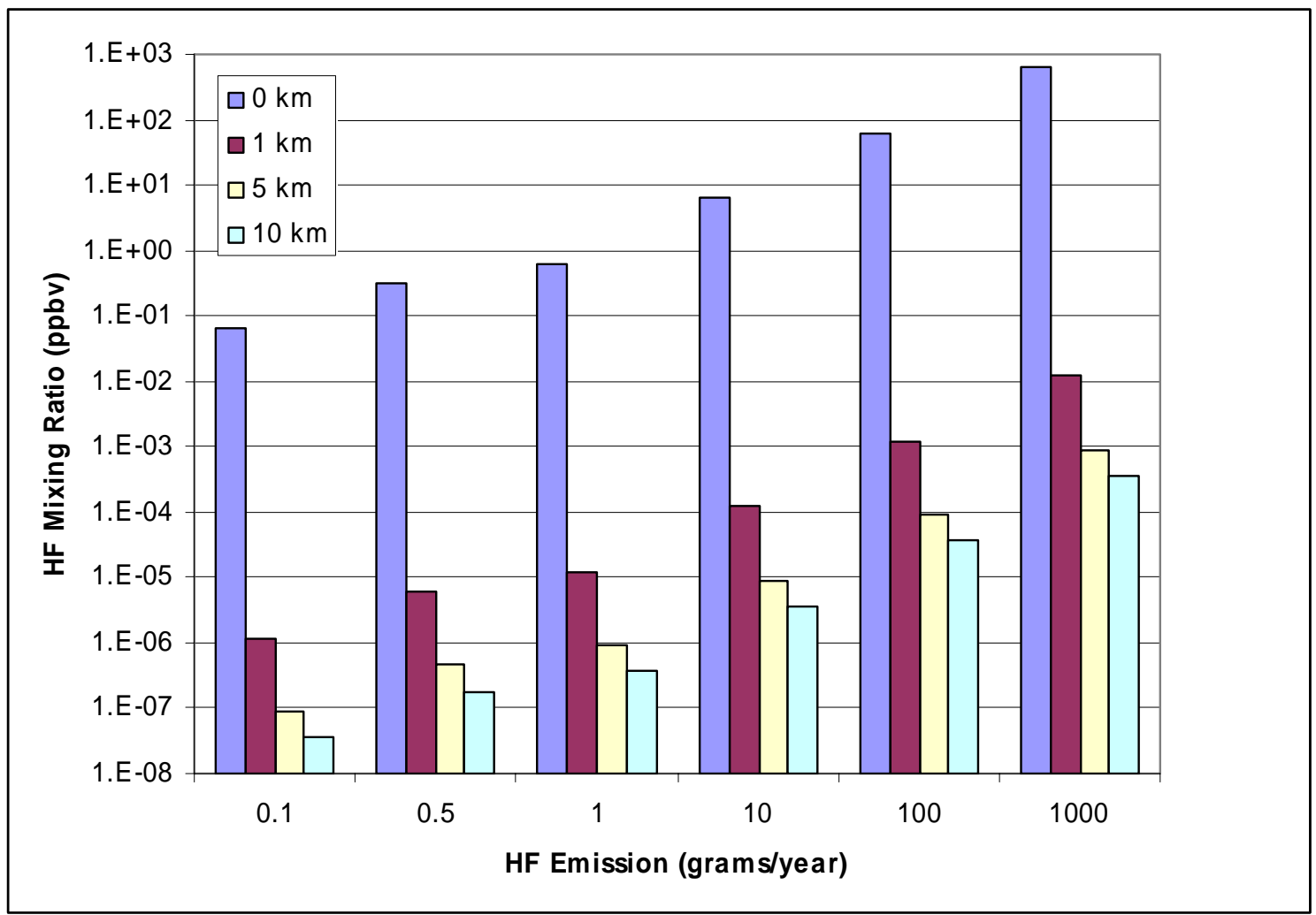

Figure 4.1 Calculated ground level HF mixing ratio $\left(\mathrm{ppb}_{\mathrm{v}}\right)$ as a function of annual HF emissions and as a function of distance from stack. Zero distance value is at the stack opening (10 meters above the ground in this case). 


\section{Diffusion Model:}

The most commonly used model for regulatory purposes is the so-called Gaussian steady-state model. It provides a steady-state solution to the transport and diffusion equations (transport plus diffusion $=$ dispersion). Steady-state implies that the basic assumption is a constant emission and constant meteorological conditions:

The basic Gaussian diffusion equations assumes:

- that atmospheric stability and all other meteorological parameters are uniform and constant throughout the layer into which the pollutants is discharged, and in particular that wind speed and direction are uniform and constant in the domain;

- that turbulent diffusion is a random activity and therefore the dilution of the pollutant can be described in both horizontal and vertical directions by the Gaussian or normal distribution;

- that the pollutant is released at a height above the ground that is given by the physical stack height and the rise of the plume due to its momentum and buoyancy (together forming the effective stack height);

- that the degree of dilution is inversely proportional to the wind speed;

- that pollutant material reaching the ground level is reflected back into the atmosphere;

- that the pollutant is conservative, i.e., not undergoing any chemical reactions, transformation or decay.

The model equations:

The spatial dynamics of pollution dispersion is described by the following type of equation in a Gaussian model:

$$
C(x, y, z, t)=\frac{Q}{2 \pi \cdot u \sigma_{y} \cdot \sigma_{x}} \cdot \exp \left(-\frac{y^{2}}{2 \sigma_{y}^{2}}\right)_{-}^{-} \exp \left(-\frac{\left(z-H_{b i}\right)^{2}}{2 \sigma_{x}^{2}}\right]+\exp \left[-\frac{\left(z+H_{t \theta}\right)^{2}}{2 \sigma_{z}^{2}}\right)
$$

$\mathrm{C}(\mathrm{x}, \mathrm{y}, \mathrm{z})$ : pollutant concentration at point $(\mathrm{x}, \mathrm{y}, \mathrm{z})$;

where

- $\quad \mathrm{U}$ : wind speed (in the $\mathrm{x}$ "downwind" direction, $\mathrm{m} / \mathrm{s}$ )

- $\sigma$ represents the standard deviation of the concentration in the $\mathrm{x}$ and $\mathrm{y}$ direction, i.e., in the wind direction and cross-wind, in meters;

- $\mathrm{Q}$ is the emission strength $(\mathrm{g} / \mathrm{s})$

- $\mathrm{H}_{\mathrm{eff}}$ is the effective stack height.

From the above equation one can deduce, in steady state, the concentration in any point $(\mathrm{x}, \mathrm{y}, \mathrm{z})$ in the model domain, from a constant emission rate. 


\subsection{FY05 Research Plans}

Objective A: Explore cavity ringdown techniques which allow for the broadest possible application to proliferation detection.

Approach: Current generation cavity ringdown instruments are ideally suited for the detection of molecules with well resolved ro-vibrational spectra. Quantitative concentration determination is straight forward if line profiles can be measured (or at least peak to baseline values obtained). The vast majority of molecules that are of interest for proliferation detection do not have such well resolved structure. It would be desirable to record broad spectra (sufficient to identify and fit absorption bands) using the cavity ringdown technique. Presently we can do this but it takes time. A $200 \mathrm{~cm}^{-1}$ scan may take 20 minutes or more, this is unacceptable for any kind of active sensor. Fortunately there has been progress on developing broadband cavity ringdown spectroscopy as a technique for measuring broad spectral features. Many kinds of optical sources can be used in which a wide spectral profile is applied to the cavity from which only the frequencies that are resonant are "allowed" to enter the cavity. On the output of the cavity a wavelength dispersive device resolves the different components onto separate detector elements (or a single element in a scanning device). Several different techniques have been shown to allow the simultaneous measurement of many wavelengths and their ringdowns in a single shot. New to these techniques is the use of a mode-locked laser whose cavity free-spectral range matches either the ringdown cavity's FSR or an integer multiple. In this way most (or all) the laser light is used in the cavity, as opposed to other broadband laser techniques where a large fraction of light simply reflects off the front mirror of the cavity. It is proposed here to investigate the use of a $75 \mathrm{MHz}$ mode locked laser matched with the $300 \mathrm{MHz}$ cavity ringdown system (where every fourth mode of the laser is injected into the cavity) to establish the utility of such a system for quantitative measurements of broad band absorbers.

Timetable: Ongoing throughout the fiscal year.

Objective B: To reduce the size (i.e., volume and weight) of the current instrument while trying to maintain a certain level of instrument performance.

Approach: Plans have been developed and are being executed which will reduce the current instrument configuration consisting of a crate holding the optics and an instrument rack holding the vacuum and electronic to a single crate holding the required components. This corresponds to a volume reduction of $65 \%$ (47 cubic feet to 16 cubic feet). While the final electrical consumption values are still being calculated it is estimated that electrical consumption will be reduced from 1 kilowatt to less than 400 watts. An area of significant size reduction has come by deleting nearly all of the vacuum equipment from the system. Only the vacuum pump and one electrically controlled valve will remain. Additionally the optical bench-top area will be reduced by $25 \%$.

Timetable: The current system will be transferred into this new configuration by the beginning of Q3 FY05. Truck mounted demonstrations will proceed after that demonstrating vehicle borne cavity ringdown operation. 
Objective C: Participate in the Shrike Field test scheduled for the week of July $11^{\text {th }}$ at the Nevada Test Site. 


\section{Distribution}

No. of

\section{Copies}

\section{OFFSITE}

LTC Ariel Cuadrado

United States DOE

NNSA/NA-22

1000 Independence Ave. SW

Washington, DC 20585

Dr. Rhys M. Williams

United States DOE

NNSA/NA-22

1000 Independence Ave. SW

Washington, DC 20585

Dr. Michael Meier

United States DOE

NNSA/NA-22

1000 Independence Ave. SW

Washington, DC 20585

Dr. David Berry

United States DOE

NNSA/NA-22

1000 Independence Ave. SW

Washington, DC 20585

Mr. Ralph Hastings

United States DOE

NNSA/NA-22

1000 Independence Ave. SW

Washington, DC 20585

Mr. Eric Sanders

United States DOE

NNSA/NA-22

1000 Independence Ave. SW

Washington, DC 20585
No. of

Copies

Mr. W. Randy Bell

United States DOE

NNSA/NA-22

1000 Independence Ave. SW

Washington, DC 20585

Dr. Vaughn Standley

United States DOE

NNSA/NA-22

1000 Independence Ave. SW

Washington, DC 20585

LTC John C. Carrano, PhD

Program Manager

DARPA, MTO

3701 N. Fairfax Dr.

Arlington, VA 22203-1714

\section{ONSITE}

\section{Pacific Northwest National Laboratory}

Bruckner-Lea, C K5-25

Clemmer, RG K8-29

Dudder, GB K8-29

Schultz, JF (10) K5-25

Stewart, TL K5-25

Thompson, JS K5-25

Tweedy, BJ K5-25

Williams, RM K5-25

Information Release Office (7) K1-06 
